\title{
Sydenham's chorea in a family with Huntington's disease: case report and review of the literature
}

\author{
Coreia de Sydenham numa família com doença de Huntington: relato de caso e \\ revisão da literatura
}

\author{
Rita Santos-Silva', Susana Corujeira', Ana Filipe Almeida', Sofia Granja", Cláudia Moura"', Inês Azevedo'v', Miguel Leãov , Ana Maiavı \\ Department of Pediatrics, Hospital São João, and School of Medicine of Porto University, Porto, Portugal
}

'MD. Resident in Pediatrics, Department of Pediatrics, Hospital São João, Porto, Portugal. "MD. Resident in Pediatric Cardiology,

Department of Pediatric Cardiology, Hospital São João, Porto, Portugal.

'"MD. Consultant Pediatric Cardiologist, Department of Pediatric Cardiology, Hospital São João, Porto, Portugal.

IvMD, PhD. Associate Professor of Pediatrics of the School of Medicine of Porto University; Pediatric Pulmonology Unit, Department of Pediatrics, Hospital São João, Porto, Portugal. vMD. Consultant Neurologist and Geneticist, Neuropediatric Unit, Department of Pediatrics, Hospital São João, Porto, Portugal.

"MD. Consultant Pediatrician, General Pediatrics Unit, Department of Pediatrics, Hospital São João, Porto, Portugal.

\section{KEY WORDS:}

Chorea.

Huntington disease.

Rheumatic fever.

Antistreptolysin.

Genetic counseling.

\section{PALAVRAS-CHAVE:}

Coréia.

Doença de Huntington.

Febre reumática.

Antiestreptolisina.

Aconselhamento genético.

\begin{abstract}
CONTEXT: Sydenham's chorea affects almost $30 \%$ of patients with acute rheumatic fever. It is more frequent in females and is rare in the first decade of life, and genetic vulnerability underlies it. Because of easy access to antibiotics, it is now rare in so-called developed countries.

CASE REPORT: A 6-year-old boy with a family history of Huntington's disease, who was the only child of an unscreened and asymptomatic mother, was brought for a consultation because of migratory arthralgia, depressed mood, and rapid, abrupt and unintentional movements of his right arm and leg, that had evolved over a three-week period. On physical examination, he presented a grade III/VI systolic heart murmur and right-side choreic movements, giving rise to a deficit of active mobilization. Laboratory tests revealed elevated erythrocyte sedimentation rate $(63 \mathrm{~mm} / \mathrm{h})$, C-reactive protein $(25 \mathrm{mg} / \mathrm{l})$ and antistreptolysin $\mathrm{O}$ titer $(1,824 \mathrm{U} / \mathrm{ml})$. Cardiovascular evaluation showed mild aortic insufficiency, moderate mitral insufficiency and a prolonged PR interval. A clinical diagnosis of Sydenham's chorea/acute rheumatic fever was made, and therapy consisting of penicillin, haloperidol, captopril and furosemide was instituted, with excellent results.

CONCLUSION: In developed countries, Sydenham's chorea seems forgotten and, because of this, little is known about its clinical course and controversy surrounds the therapeutic options available. This occurrence of rheumatic chorea in a family with Huntington's disease highlights the importance of the differential diagnosis for the different forms of chorea.
\end{abstract}

\section{RESUMO}

CONTEXTO: A coreia de Sydenham surge em cerca de 30\% dos casos de febre reumática aguda. É mais frequente no sexo feminino, é rara na primeira década de vida e tem por base uma vulnerabilidade genética. Devido ao fácil acesso aos antibióticos, é uma doença rara atualmente nos países ditos desenvolvidos. RELATO DO CASO: Criança de seis anos, sexo masculino, com história familiar de coreia de Huntington, único filho de mãe assintomática e não rastreada, foi trazido à consulta por artralgias migratórias, humor deprimido e movimentos rápidos, abruptos e não intencionais dos membros superior e inferior direitos, com três semanas de evolução. Ao exame físico, apresentava um sopro cardíaco sistólico grau III/VI, e foram presenciados movimentos coreicos à direita, condicionando um défice de mobilização activa. Os exames laboratoriais mostraram aumento da velocidade de sedimentação $(63 \mathrm{~mm} / \mathrm{h}$ ), proteína C-reativa $(25 \mathrm{mg} / \mathrm{L})$ e título de antiestreptolisina $\mathrm{O}$ (1.824 U/mL). O exame cardiovascular revelou insuficiência aórtica ligeira e insuficiência mitral moderada e aumento do intervalo PR. Foi feito o diagnóstico de coreia de Sydenham/febre reumática aguda, tendo sido instituída terapêutica com penicilina, haloperidol, captopril e furosemida, com excelente resultado. CONCLUSÃO: Nos países desenvolvidos, a coreia de Sydenham parece esquecida e, por isso, pouco se sabe quanto ao seu curso clínico e as opções terapêuticas disponíveis são controversas. A ocorrência de um caso de coreia reumática numa família com doença de Huntington realça a importância do diagnóstico diferencial das diferentes formas de coreia. 


\section{INTRODUCTION}

Chorea is a manifestation in a large number of disorders, both acquired and inherited, including metabolic, infectious, inflammatory and neurodegenerative diseases. Sydenham's chorea (SC) is the most common form of childhood chorea, while Huntington's disease (HD) accounts for the majority of adult-onset cases. $^{1}$

\section{CASE REPORT}

The case of a six-year-old boy who was previously healthy, but had a family history of Huntington's disease (five relatives affected, of whom two had the juvenile form of the disease) is presented here. His mother had not been screened but was asymptomatic.

He was brought to the outpatient clinic of a tertiary-care hospital in Portugal because of migratory arthralgia (without arthritis), asthenia, depressed mood and rapid, abrupt and unintentional movements of his right arm and leg (leading to severe incapacity to eat and write). The symptoms had begun three weeks earlier and he had a history of febrile syndrome, which had occurred approximately one month before the onset of his symptoms. He had not received any specific treatment and there was no history of drug use or medication allergies.

On physical examination, he presented a grade III/VI systolic murmur at the left sternal border and choreic movements in both right limbs.

Laboratory tests revealed that his complete blood cell count and blood chemistry panels were normal, but he presented elevated erythrocyte sedimentation rate $(63 \mathrm{~mm} / \mathrm{h})$ and C-reactive protein $(25 \mathrm{mg} / \mathrm{l})$. The antistreptolysin O titer was $1824 \mathrm{U} / \mathrm{ml}$ and the antineuronal antibody test was negative. The cardiac evaluation showed mild aortic insufficiency and moderate mitral insufficiency, and a prolonged PR interval.

Other tests performed presented normal results, including brain magnetic resonance imaging (MRI), autoimmunity evaluation (anticardiolipin antibodies, antinuclear antibodies and complement levels), viral serological tests (human immunodeficiency virus, parvovirus B19, cytomegalovirus, Epstein-Barr virus and hepatitis $\mathrm{C}$ and $\mathrm{B}$ viruses), venereal disease research laboratory test (VDRL), blood culture and thyroid function.

The clinical picture of migratory arthralgia, rheumatic carditis and hemichorea made a diagnosis of Sydenham's chorea/acute rheumatic fever very likely. The patient was treated with benzathine penicillin $(1,200,000 \mathrm{U})$, haloperidol $(0.5 \mathrm{mg}$ per day on the first three days and then $1 \mathrm{mg}$ twice a day), captopril (12.5 $\mathrm{mg}$ three times a day) and furosemide (10 $\mathrm{mg}$ three times a day). He was discharged five days after the beginning of the treatment, with improved mood and better control over the choreic movements. One month later, he was back to his baseline behavior and the choreic movements and hypotonia had practically disappeared.

\section{DISCUSSION}

Rheumatic fever (RF) is a nonsuppurative complication of group A beta-hemolytic streptococcal sore throat. Although rare in developed countries, RF is still present and should not be neglected. The incidence of this disease in the United States is approximately $0.5-2$ cases per 100,000 population per year. ${ }^{2}$ Statistics concerning the incidence of this disorder in Portugal are not available. Sydenham's chorea (SC) may be present in almost $30 \%$ of patients with RF. The female-to-male ratio is $2: 1$, with familial predisposition, and the age of presentation is usually between 5 and 15 years. $^{3}$

The main features of SC are behavioral changes (depression, anxiety, personality changes and emotional lability), hypotonia and purposeless movements that are aggravated by stress and absent during sleep. In $20 \%$ of these patients, only one side of the body is affected (so-called hemichorea), as in our case. ${ }^{4-6}$

RF diagnosed before the age of 10 years may be very different, because younger children are more likely to present arthritis and carditis but less likely to present chorea. ${ }^{3,6}$ However, in our case, all three of these occurred simultaneously, and the neurological manifestations were the most disabling of them.

The diagnosis of SC continues to be determined on clinical grounds, since no laboratory or imaging test can be considered to be confirmatory. Absence of a history or serological markers of prior streptococcal infection does not rule out the diagnosis of SC. Antineuronal antibodies have been found in the cerebrospinal fluid of $90 \%$ of patients with SC, and some studies have shown abnormal findings on MRI. ${ }^{4}$ In our case, antineuronal antibodies tested negative and MRI was normal, but there was a very high antistreptolysin $\mathrm{O}$ titer and there was a history of a prolonged febrile syndrome prior to the onset of symptoms that might correspond to the streptococcal infection.

$\mathrm{SC}$ resolves spontaneously in three to six months and, because of this, treatment should be limited to patients with severe chorea. Chorea may be controlled using either dopaminergic blockers (haloperidol or pimozide) or anticonvulsants (valproic acid and carbamazepine). Valproic acid has been recommended as the first-line treatment for SC. ${ }^{7-9}$ Penicillin should be used for all patients, including those with chorea alone. ${ }^{10}$ In the presence of antineuronal antibodies, intravenous immunoglobulin and plasma exchange are thought to be effective. ${ }^{8} 9$ Steroid therapy has been used in cases of severe carditis or whenever the neurological symptoms do not respond to dopaminergic blockers. ${ }^{8,9}$ In this particular case, we used haloperidol, with excellent results and no adverse effects, and thus without the need of any additional therapy.

Secondary prophylaxis with intramuscular benzathine penicillin every four weeks is indicated after RF to prevent further damage to cardiac valves. According to the American Heart Association, patients with RF without carditis should receive 
prophylactic antibiotics for five years or until aged 21; patients with RF with carditis but no valve disease should receive prophylactic antibiotics for 10 years or until 21 years of age; and patients with RF with persistent valve disease, as was the case of our patient, should receive prophylactic antibiotics ad infinitum or at least until 40 years of age. ${ }^{10}$

The prognosis for SC cases is usually good, but about $20 \%$ of patients experience recurrences within two years after the initial attack. The risk of developing psychiatric illness in adulthood, namely obsessive-compulsive disorder, is still a matter of controversy. ${ }^{4}$ In our case, there were no significant doubts concerning the diagnosis of SC because of the presence of carditis, migratory arthralgia, chorea and increased antistreptolysin $\mathrm{O}$ titer. However, other causes of chorea were considered in the differential diagnosis. First of all, other immune-mediated types of chorea, such as lupus chorea (LC), were taken into consideration. Although central nervous system involvement in cases of lupus erythematosus is common (70\%), LC has been reported in less than $2 \%$ of the patients and it usually appears at a later stage of the disease. ${ }^{11}$ In our case, the autoimmunity evaluation was normal and there were no other manifestations of lupus, including no abnormal findings on MRI.

Another differential diagnosis to be considered is benign hereditary chorea (BHC), an autosomal dominant disorder characterized by generalized choreic movements, which usually begins in early childhood. Its severity is variable, but this condition is non-progressive and tends to disappear during adolescence, and intellectual function is typically normal. ${ }^{11}$ In our case, there was no family history of BHC; the patient had hemichorea (as opposed to the generalized choreic movements typical of BHC); there was an obvious cardiac involvement; and the erythrocyte sedimentation rate and antistreptolysin levels were elevated.

Curiously, we were dealing with a family with a history of Huntington's disease (HD). As far as we know, this is the first case of rheumatic chorea in a family with Huntington's disease. We carried out a systematic analysis of the indexed articles published and we only found a few reviews concerning the two subjects and some case series of "chorea". There were no cases like ours published in the main databases (Table 1).

$\mathrm{HD}$ is an autosomal dominant disorder with complete penetrance but age dependence, and it usually begins in the fourth decade of life. Some cases have been reported in young children, but the juvenile-onset form (Westphal variant) of chorea is usually rare and the typical presentation is a "Parkinson-like" syndrome, with rigidity, ataxia, seizures, cognitive decline and a tendency towards insanity and suicide. ${ }^{11-13}$ This diagnosis was ruled out in the light of the neurological manifestations and the presence of carditis. Even though a predictive genetic test is available, there is an international ethical consensus that considers
Table 1. Results from reviewing the medical databases regarding the association between Sydenham's chorea and Huntington's disease

$\begin{array}{lll}\text { Data } & \text { Search Strategy } & \text { Results } \\ & \begin{array}{l}\text { "Sydenham's chorea" AND "Huntington's } \\ \text { disease", or "Rheumatic chorea" AND } \\ \text { "Huntington's disease" }\end{array} & \begin{array}{l}9 \text { reviews } \\ 6 \text { case series }\end{array} \\ \text { PubMed } & & \begin{array}{l}2 \text { case reports } \\ 1 \text { clinical trial }\end{array} \\ & & 1 \text { experimental study } \\ & & 1 \text { case-control study } \\ & \text { "Sydenham's chorea" AND "Family with } & 2 \text { case series } \\ \text { Lilacs } & \text { Huntington's disease" } & 2 \text { reviews } \\ \text { Embase } & \text { "Sydenham" AND "Huntington" } & 1 \text { review } \\ & & 1 \text { case series }\end{array}$

that presymptomatic diagnosing of adult-onset disorders that do not have any preventive or curative treatment should only be requested or performed after obtaining fully informed consent and expression of will from capable individuals who are no longer minors. ${ }^{14}$ In our case, taking into account the family history (maternal grandfather affected by HD and the mother's refusal to undergo the presymptomatic diagnosis), genetic counseling would rely on a probabilistic approach, since the theoretical risk of developing HD in our patient was $25 \%$.

\section{REFERENCES}

1. Weiner SG, Normandin PA. Sydenham chorea: a case report and a review of the literature. Pediatr Emerg Care. 2007;23(1):20-4.

2. Cardoso F, Seppi K, Mair KJ, Wenning GK, Poewe W. Seminar on choreas. Lancet Neurol. 2006:5(7):589-602.

3. Tani LY, Veasy G, Minich LL, Shaddy RE. Rheumatic fever in children younger than 5 years: is the presentation different? Pediatrics. 2003;112(5):1065-8

4. Kliegman RM, Behrman Rl, Jenson HB, et al. Nelson textbook of pediatrics. Philadelphia: Saunders Elsevier; 2007

5. Spina GS. Doença reumática: negligenciada, mas ainda presente e mortal [Rheumatic disease: nelected but still present and deadly]. Rev Med (São Paulo). 2008;87(2):128-41.

6. Stollerman GH. Rheumatic fever in the 21st century. Clin Infect Dis. 2001;33(6):806-14

7. Working Group on Pediatric Acute Rheumatic Fever and Cardiology Chapter of Indian Academy of Pediatrics, Saxena A, Kumar RK, et al. Consensus guidelines on pediatric acute rheumatic fever and rheumatic heart disease. Indian Pediatr. 2008;45(7):565-73.

8. Genel F, Arslanoglu S, Uran N, Saylan B. Sydenham's chorea: clinical findings and comparison of the efficacies of sodium valproate and carbamazepine regimens. Brain Dev. 2002;24(2):73-6.

9. Teixeira Jr AL, Maia DP, Cardoso F. Treatment of acute Sydenham's chorea with methyl-prednisolone pulse-therapy. Parkinsonism Relat Disord. 2005;11(5):327-30.

10. Gerber MA, Baltimore RS, Eaton CB, et al. Prevention of rheumatic fever and diagnosis and treatment of acute Streptococcal pharyngitis: a 
scientific statement from the American Heart Association Rheumatic Fever, Endocarditis, and Kawasaki Disease Committee of the Council on Cardiovascular Disease in the Young, the Interdisciplinary Council on Functional Genomics and Translational Biology, and the Interdisciplinary Council on Quality of Care and Outcomes Research: endorsed by the American Academy of Pediatrics. Circulation. 2009;119(11):1541-51.

11. Bhidayasiri R, Truong DD. Chorea and related disorders. Postgrad Med J. 2004;80(947):527-34

12. Gonzalez-Alegre P, Afifi AK. Clinical characteristics of childhood-onset (juvenile) Huntington disease: report of 12 patients and review of the literature. J Child Neurol. 2006;21(3):223-9.

13. Ruocco HH, Lopes-Cendes I, Laurito TL, Li LM, Cendes F. Clinical presentation of juvenile Huntington disease. Arq Neuropsiquiatr. 2006;64(1):5-9.

14. Toufexis M, Gieron-Korthals M. Early testing for Huntington disease in children: pros and cons. J Child Neurol. 2010;25(4):482-4.

Place and event at which the paper was presented: Case report presented previously at the $28^{\text {th }}$ Annual Meeting of the European Society for Paediatric Infectious Diseases (ESPID), in Nice, France, on May 4-8, 2010, as a poster and included in the abstract book

\title{
Sources of funding: None
}

Conflict of interest: None

Date of first submission: May 20, 2010

Last received: December 15, 2010

Accepted: March 22, 2011

\author{
Address for correspondence: \\ Rita Santos-Silva \\ Rua Diogo Afonso, 71 \\ Habitação 41. 4150-254 Porto. Portugal \\ Tel: +351936273702 \\ E-mail: ritasantossilva@gmail.com
}

